\title{
Faktor Risiko Timbulnya Inhibitor Faktor VIII pada Anak dengan Hemofilia A
}

Grace N.A. Simatupang, Endang Windiastuti, Hanifah Oswari

Departemen Ilmu Kesehatan Anak Fakultas Kedokteran Universitas Indonesia RS Cipto Mangunkusumo, Jakarta

Latar belakang. Proses timbulnya inhibitor bersifat multifaktorial, baik genetik maupun lingkungan. Beberapa studi telah dilakukan untuk mengetahui faktor risiko terbentuknya inhibitor, namun masih terdapat pendapat yang kontroversial. Di Indonesia, skrining inhibitor tidak rutin dilakukan karena keterbatasan biaya dan alat, sehingga diperlukan suatu penelitian yang dapat dijadikan acuan pemeriksaan inhibitor selektif. Tujuan. Mengetahui prevalensi , karakteristik klinis, dan faktor risiko timbulnya inhibitor pada anak dengan hemofilia A di Departemen IKA- RSCM.

Metode. Uji potong lintang dilakukan pada anak usia $\leq 18$ tahun di Pusat Hemofilia Terpadu IKA-RSCM. Analisis bivariat dilakukan dengan uji Fisher. Analisis multivariat tidak dilakukan karena tidak memenuhi syarat.

Hasil. Empatpuluh subjek penelitian, didapatkan prevalensi inhibitor 37,5\% (15/40). Rentang usia subjek 10 (1,5-18) tahun, usia saat diagnosis hemofilia pertama kali ditegakkan 8 bulan, dan saat pertama kali mendapat terapi faktor VIII pada inhibitor positif 9 bulan. Hampir seluruh subjek (39/40) mendapat terapi konsentrat plasma, 11/15 subjek dengan inhibitor positif mendapat terapi pertama kali sebelum berusia 1 tahun, 14/15 subjek merupakan hemofilia berat, sebagian besar (12/15) mendapat manifestasi perdarahan sendi. Suku bangsa ibu, Jawa, lebih sering ditemukan pada inhibitor positif (8/15). Tidak ditemukan hasil yang bermakna secara statistik antara faktor risiko dengan timbulnya inhibitor.

Kesimpulan. Prevalensi inhibitor 37,5\%, inhibitor positif lebih sering ditemukan pada pasien hemofilia berat yang mendapat terapi pertama kali sebelum berusia 1 tahun. Penelitian kami tidak berhasil membuktikan faktor risiko bermakna untuk timbulnya inhibitor pada anak dengan hemofilia A. Sari Pediatri 2013;14(5):320-5.

Kata kunci: hemofilia A, inhibitor faktor VIII, faktor risiko

\footnotetext{
Alamat korespondensi:

Dr. Endang Windiastuti, SpA(K). Divisi Hematologi Onkologi Departemen Ilmu Kesehatan Anak FKUI- RSCM Jl. Salemba no. 6, Jakarta 10430. Telepon: 021-3907744, 31901170 Fax.021-3913982.
}

I nhibitor merupakan suatu imunoglobulin G yang dapat menetralisasi aktivitas faktor VIII pada pasien hemofilia A. ${ }^{1}$ Timbulnya inhibitor seringkali tidak disadari, dan biasanya ditemukan pada saat timbul perdarahan yang sulit diatasi dengan tatalaksana biasa, atau ditemukan secara kebetulan pada saat pemeriksaan rutin. ${ }^{1}$ Proses terbentuknya inhibitor bersifat multifaktorial, terdiri dari faktor genetik dan lingkungan. ${ }^{2,3}$ Beberapa penelitian telah dilakukan 
untuk mengetahui faktor yang berperan terhadap timbulnya inhibitor, namun masih terdapat perbedaan pendapat. ${ }^{4-8}$ Evaluasi kadar inhibitor seharusnya dilakukan setiap tahun, namun hal tersebut tidak rutin dilakukan di Indonesia karena sarana pemeriksaan yang terbatas, serta biaya yang cukup mahal.

Tujuan penelitian kami untuk mengetahui prevalensi, karakteristik klinis, dan faktor risiko timbulnya inhibitor pada anak dengan hemofilia A di Departemen IKA- RSCM. Diharapkan data yang didapat, dapat dijadikan acuan pemeriksaan inhibitor selektif pada pasien hemofilia di RSCM.

\section{Metode}

Uji potong lintang dilakukan pada anak usia $\leq 18$ tahun dengan hemofilia A yang mempunyai data kadar faktor VIII di Pusat Hemofilia Terpadu IKA-RSCM. Orangtua subjek diberi penjelasan mengenai tujuan, prosedur, manfaat, serta risiko penelitian (informed consent). Apabila setuju, maka diminta menandatangani surat persetujuan, dan mengisi kuesioner mengenai usia saat pertama kali didiagnosis hemofilia, mendapat terapi faktor VIII, jenis terapi pengganti, derajat hemofilia, jenis perdarahan, dan suku bangsa ibu pasien. Pada subjek dilakukan pengambilan darah vena $5 \mathrm{~mL}$, dan dilakukan pemeriksaan inhibitor menggunakan metode Bethesda assay di laboratorium patologi klinik RSCM. Pemeriksaan dilakukan dengan mencampurkan plasma individu normal dengan subjek, dan diinkubasi selama dua jam pada suhu $37^{\circ} \mathrm{C}$. Dilakukan pemeriksaan aktivitas kadar faktor VIII, kemudian disesuaikan dengan kurva untuk mendapatkan nilai inhibitor dalam Bethesda unit (BU). Satu BU didefinisikan sebagai inhibitor faktor VIII yang menginaktifkan 50\% dari jumlah awal kadar faktor VIII dalam plasma normal. Analisis bivariat dilakukan dengan uji Fisher. Analisis multivariat tidak dilakukan karena tidak memenuhi syarat. Penelitian kami telah disetujui oleh komisi etik penelitian Fakultas Kedokteran Universitas Indonesia.

\section{Hasil}

Selama kurun waktu penelitian didapatkan 40 subjek yang memenuhi kriteria penerimaan. Terdapat 15 dari 40 subjek dengan inhibitor positif $(37,5 \%)$. Rentang kadar inhibitor 1,1 (0,3-88) BU. Rentang

Tabel 1. Karakteristik dasar subjek penelitian $(n=40)$

\begin{tabular}{lcc}
\hline Parameter & \multicolumn{2}{c}{ Inhibitor } \\
\cline { 2 - 3 } & Positif $(\mathrm{n}=15)$ & Negatif $(\mathrm{n}=25)$ \\
\hline Usia saat ini (tahun) & $7 / 15$ & $6 / 25$ \\
$\quad<5$ & $8 / 15$ & $19 / 25$ \\
$\quad \geq 5-18$ & $0,8(0,4-7)$ & $1(0,3-11)$ \\
Usia saat diagnosis hemofilia ditegakkan & & \\
(rentang, tahun) & $0,9(0,4-10)$ & $1,1(0,5-11)$ \\
Usia saat mendapat terapi pengganti & & \\
(rentang, tahun) & & \\
Jenis perdarahan & $12 / 15$ & $20 / 25$ \\
Sendi & $2 / 15$ & $5 / 25$ \\
Otot & $1 / 15$ & $0 / 25$ \\
Intrakranial & & \\
Jenis terapi pengganti & $0 / 15$ & $24 / 25$ \\
Kriopresipitat & $15 / 15$ & \\
Konsentrat plasma & & $6 / 25$ \\
Suku bangsa ibu subjek & $8 / 15$ & $11 / 25$ \\
Jawa & $3 / 15$ & $4 / 25$ \\
Sunda & $2 / 15$ & $2 / 25$ \\
Betawi & $0 / 15$ & $0 / 25$ \\
Manado & $1 / 15$ & $1 / 25$ \\
Ambon & $1 / 15$ & $1 / 25$ \\
Cina & $0 / 15$ & \\
Padang & & \\
\hline
\end{tabular}


Grace N.A. Simatupang dkk: Faktor risiko timbulnya inhibitor faktor VIII pada anak dengan hemofilia A

Tabel 2. Analisis bivariat faktor risiko timbulnya inhibitor faktor VIII $(\mathrm{n}=40)$

\begin{tabular}{|c|c|c|c|c|c|}
\hline \multirow[t]{2}{*}{ Faktor risiko } & \multicolumn{2}{|c|}{ Inhibitor } & \multirow[t]{2}{*}{$\mathrm{p}$} & \multirow[t]{2}{*}{$\mathrm{RO}$} & \multirow[t]{2}{*}{ IK 95\% } \\
\hline & Positif $(n=15)$ & Negatif $(n=25)$ & & & \\
\hline \multicolumn{6}{|l|}{$\begin{array}{l}\text { Usia mendapat terapi } \\
\text { faktor VIII (tahun) }\end{array}$} \\
\hline $0-1$ & $11 / 15$ & $10 / 25$ & $0,336^{\#}$ & 2,031 & $(0,45-1,28)$ \\
\hline$>1$ & $4 / 15$ & $15 / 25$ & & & \\
\hline \multicolumn{6}{|l|}{ Jenis terapi pengganti } \\
\hline Kriopresipitat & $0 / 15$ & $1 / 25$ & $1,000^{\#}$ & 0,601 & $(0,46-1,78)$ \\
\hline Konsentrat plasma & $15 / 15$ & $24 / 25$ & & & \\
\hline \multicolumn{6}{|l|}{ Derajat hemofilia } \\
\hline Ringan* & $0 / 15$ & $1 / 25$ & & & \\
\hline Sedang & $1 / 15$ & $6 / 25$ & $1,000^{\#}$ & 1,107 & $(0,86-1,57)$ \\
\hline Berat & $14 / 15$ & $18 / 25$ & $1,000^{\#}$ & 1,778 & $(0,67-1,41)$ \\
\hline \multicolumn{6}{|l|}{ Jenis perdarahan } \\
\hline Sendi & $12 / 15$ & $20 / 25$ & $0,444^{\#}$ & 1,313 & $(0,62-1,74)$ \\
\hline Non sendi & $3 / 15$ & $5 / 25$ & & & \\
\hline
\end{tabular}

kadar inhibitor pada inhibitor positif low responder 0,73 (0,30-4,70) BU dan high responder 44,8 (8,6 88) BU.

Karakteristik klinis subjek tertera pada Tabel 1. Rentang usia subjek 10 (1,5-18) tahun. Perdarahan sendi tersering ditemukan, baik pada subjek dengan inhibitor positif, maupun negatif. Perdarahan intrakranial terjadi pada satu subjek hemofilia berat berusia dua tahun yang mempunyai kadar inhibitor tertinggi, yaitu 88 BU. Pada penelitian kami, hampir seluruh subjek mendapat terapi konsentrat plasma/ Koate®, dan merupakan subjek hemofilia berat. Suku bangsa ibu, Jawa dan Sunda, merupakan suku terbanyak didapatkan pada subjek dengan inhibitor positif maupun negatif.

Kami mendapatkan tiga pasang saudara kandung yang merupakan subjek dengan hemofilia berat. Dua pasang saudara kandung mendapat hasil inhibitor negative, sementara satu pasang lain masing-masing mendapat inhibitor negatif, dan inhibitor low responder $(1,10 \mathrm{BU})$. Subjek tersebut mendapat terapi faktor VIII pertama kali pada usia 5 bulan, sementara yang lain setelah berusia 1 tahun.

Tabel 2 menjelaskan perbandingan empat faktor risiko terhadap timbulnya inhibitor pada subjek yang dinyatakan dalam bentuk rasio odds (RO). Faktor risiko yang dinilai, yaitu usia saat pertama kali mendapat faktor VIII, derajat hemofilia, jenis terapi pengganti, dan jenis perdarahan tidak menunjukkan hubungan dengan terbentuknya inhibitor faktor VIII $(\mathrm{p}>0,05)$.

Analisis multivariat tidak dapat dilakukan karena semua variabel tidak memiliki nilai $\mathrm{p}<0,25$ sehingga analisis dihentikan sampai analisis bivariat.

\section{Pembahasan}

\section{Prevalensi inhibitor faktor VIII}

Prevalensi inhibitor pada penelitian kami $37,5 \%$ dengan sebaran antara 0,3 BU sampai dengan 88 BU. Prevalensi inhibitor pada hemofilia A bervariasi antar ras, namun secara keseluruhan berkisar antara 3,6\%-52\% dengan prevalensi terbesar pada ras AfrikaAmerika, Kaukasian, dan Latin. ${ }^{9,10}$ Namun, apabila dibandingkan dengan penelitian lain yang dilakukan di Asia, yaitu Taiwan (10,4\%), Cina (1,4\%), Jordania (9\%), dan Saudi Arabia (9,7\%), prevalensi pada penelitian kami jauh lebih tinggi,..114

Hasil penelitian kami hampir sama dengan studi Harijadi $^{15}$ di RSCM (2004), pada pasien hemofilia A berat yang mendapat prevalensi inhibitor sebesar $35 \%$. Prevalensi yang lebih besar pada penelitian kami, masih 
dapat disebabkan karena tidak dapat disingkirkan kemungkinan inhibitor yang bersifat transien karena pemeriksaan hanya dilakukan satu kali dan sewaktu. Selain itu, perbedaan usia subjek mendapat terapi profilaksis, atau on demand, dan perbedaan jenis terapi pengganti yang diberikan dapat memengaruhi hasil penelitian kami dibandingkan penelitian lainnya.

Studi populasi di Inggris oleh Hay dkk, ${ }^{16}$ melaporkan insidens inhibitor tertinggi dengan kadar high responder tersering terjadi pada usia $0-4$ dan $\geq 60$ tahun. Hasil yang sama ditemukan pada penelitian kami, yaitu usia subjek yang mendapat inhibitor high responder adalah 2 tahun dengan kadar tertinggi 88 $\mathrm{BU}$, dan merupakan pasien hemofilia berat.

\section{Faktor risiko terbentuknya inhibitor faktor VIII}

\section{Usia saat mendapat terapi faktor VIII}

Kontroversi usia, saat pertama kali mendapat terapi pengganti sebagai salah satu faktor risiko timbulnya inhibitor masih diperdebatkan..$^{4-8,17}$ Beberapa penelitian yang mengelompokkan usia mendapat terapi pengganti pertama kali pada usia 0-6, 6-12 bulan, dan di atas 1 tahun, menemukan hubungan antara usia mendapat terapi dengan timbulnya inhibitor. ${ }^{4,5}$

Pengelompokkan usia yang sama dengan penelitian kami terdapat pada penelitian Santagostino $\mathrm{dkk}^{17}$ dan Maclean $\mathrm{dkk}^{18}$. Studi kasus kontrol oleh Maclean dkk, ${ }^{18}$ dalam kurun waktu 25 tahun (1982-2007) tidak mendapatkan hubungan antara usia saat mendapat terapi dengan timbulnya inhibitor. Hasil yang sama didapatkan pada studi kasus kontrol yang dilakukan Santogostino $\mathrm{dkk}^{33}$ pada 183 anak. ${ }^{17}$

Perbedaan hasil beberapa penelitian tersebut dapat disebabkan karena perbedaan desain penelitian, jumlah sampel, jenis terapi pengganti yang diberikan, atau mutasi gen tertentu. Jenis mutasi gen tersering pada pasien yang mendapat terapi pada usia dini adalah intron 22 inversions sehingga diduga mutasi gen terswebut yang paling memengaruhi timbulnya inhibitor. $^{19}$

\section{Jenis terapi pengganti}

Hasil yang tidak bermakna pada penelitian kami dapat dipengaruhi oleh perbandingan yang tidak sesuai, antara jumlah subjek yang mendapat terapi konsentrat plasma (39 subjek) dan kriopresipitat (1 subjek). Namun penelitian kami mendapatkan hasil yang sama dengan Harijadi, ${ }^{10}$ yaitu subjek dengan inhibitor positif lebih banyak ditemukan pada mereka yang mendapat terapi konsentrat plasma walaupun hampir sebagian besar subjek pada penelitian Harijadi, yaitu 39 dari 45 subjek mendapat terapi kriopresipitat.

Untuk menghindari penularan infeksi HIV dan hepatitis C, maka saat ini terapi kriopresipitat telah ditinggalkan di negara maju. Saat ini, pilihan terapi pengganti untuk pasien hemofilia adalah konsentrat plasma, atau rekombinan sehingga studi yang sering dilakukan adalah membandingkan antara kedua jenis terapi tersebut dan hubungannya dengan pembentukan inhibitor. ${ }^{6-8}$ Namun kontroversial di antara kedua jenis produk tersebut masih diperdebatkan sejak 10 tahun terakhir. Studi SIPPET (survey of inhibitors in plasma product exposed toddlers $)^{51}$ yang saat ini sedang berjalan di Italia mencoba membandingkan antara keduanya dengan menggunakan desain uji klinis acak terutup, diharapkan studi tersebut dapat menjawab kontroversial pendapat mengenai kedua produk tersebut. $^{20}$

Menurut Goudemand, hal tersebut terkait dengan kandungan transforming growth factor $\beta$ (TGFß) dan $\checkmark W F$ yang didapatkan pada beberapa jenis konsentrat plasma. Sama seperti faktor vWF, TGFß ini mampu bersifat sebagai protektif terhadap timbulnya antibodi inhibitor faktor VIII karena mampu melindungi domain faktor VIII $\left(\mathrm{C}_{2}\right)$ yang biasanya menjadi target kerusakan oleh antibodi faktor VIII. Selain itu, beberapa produk rekombinan juga tidak mempunyai faktor vWF yang bersifat sebagai protektif terhadap inhibitor faktor VIII. ${ }^{6}$

\section{Derajat hemofilia}

Hampir seluruh subjek (14/15) dengan inhibitor positif pada penelitian kami merupakan pasien hemofilia berat. Meskipun tidak terdapat hubungan antara derajat hemofilia dengan terbentuknya inhibitor, namun beberapa penelitian yang dilakukan di negara maju mendapatkan hampir sebagian besar pasien dengan inhibitor positif merupakan pasien hemofilia berat. ${ }^{1,3-8}$ Hubungan antara derajat hemofilia dengan terbentuknya inhibitor lebih tinggi pada hemofilia berat (berkisar antara 20\%-52\%), dibandingkan pada hemofilia derajat ringan atau sedang $(3 \%){ }^{21-23}$ 
Pada pasien hemofilia berat dengan inhibitor positif lebih sering ditemukan mutasi gen intron 22. Penelitian Goudemand dkk, ${ }^{6}$ Chalmers dkk, ${ }^{19}$ dan Miller $\mathrm{dkk}^{24}$ pada ras Kaukasian dan Hispanik melaporkan hasil yang sama. Hampir seluruh pasien hemofilia A berat mempunyai defek intron 22 inversion, atau kelainan delesi besar dan hampir sebagian besar subjek tersebut mempunyai inhibitor positif.

Penelitian yang dilakukan di Asia mengenai mutasi gen masih jarang dilakukan. Hal tersebut disebabkan karena ras Asia mempunyai risiko yang lebih kecil mendapat inhibitor dibandingkan ras Afrika-Amerika dan Kaukasian. Pada ras Cina, Korea, dan Jepang ditemukan defek 22 intron inversion pada pasien hemofilia A berat dengan inhibitor positif berturutturut sebesar 38\%, 39,2\% dan 42\%. ${ }^{11,12,25}$ Sedangkan pada ras Saudi Arabia dan Jordania, defek 22 intron inversion ditemukan pada sebagian besar pasien hemofilia A berat, namun penelitian tersebut tidak menghubungkan dengan timbulnya inhibitor. ${ }^{13,14}$

\section{Jenis perdarahan}

Kami mendapatkan 12/15 subjek hemofilia berat dengan inhibitor positif mempunyai manifestasi perdarahan sendi, dan 1/15 subjek dengan perdarahan intrakranial. Sampai saat ini, peneliti belum menemukan studi mengenai hubungan antara jenis perdarahan dengan inhibitor. Namun, beberapa studi menyimpulkan hubungan antara kualitas hidup pasien hemofilia dan inhibitor, perdarahan sendi merupakan faktor predisposisinya. ${ }^{26,27}$ Studi Leissinger $\mathrm{dkk}^{26} \mathrm{dan}$ Gringeri dkk, ${ }^{27}$ melaporkan bahwa pasien hemofilia berat dengan inhibitor positif mempunyai risiko lebih tinggi dalam keterbatasan beraktivitas dan mendapat komplikasi muskuloskeletal di masa mendatang. Kedua studi ini menyimpulkan bahwa kualitas hidup pasien hemofilia berat dengan inhibitor pada jangka panjang, jauh lebih rendah dibandingkan tanpa inhibitor. ${ }^{26,27}$

Risiko perdarahan intrakranial meningkat seiring dengan beratnya derajat hemophilia pada pasien yang tidak mendapat terapi profilaksis. Hal tersebut terjadi, akibat inflamasi jaringan yang dapat menjadi danger signal yang merangsang aktivasi APC, dan pembentukan antibodi terhadap faktor VIII oleh sel B. ${ }^{8}$ Data CDC Amerika Serikat menyatakan beberapa faktor risiko perdarahan intrakranial pada hemofilia adalah usia kurang dari lima tahun, atau di atas 51 tahun, adanya inhibitor, serta infeksi HIV. Studi HIS (the hemophilia inhibitor study $)^{20}$ pada 16 pusat hemofilia di Kanada menemukan perdarahan intrakranial sebagai faktor risiko terbentuknya inhibitor. ${ }^{28}$

Kami menemukan satu pasien hemofilia berat yang mengalami perdarahan intrakranial yang disebabkan trauma. Subjek berusia 2 tahun dan mempunyai kadar inhibitor tertinggi, yaitu 88 BU. Penelitian Amelia $\mathrm{dkk},{ }^{29}$ pada pasien pasien hemofilia A di Departemen IKA-RSCM melaporkan 7,1\% (11 subjek) mengalami perdarahan intrakranial yang disebabkan trauma kepala maupun perdarahan spontan. Rentang usia pasien yang mendapat perdarahan intrakranial pada penelitian tersebut adalah 6 (3-15) tahun. ${ }^{29}$ Sebaiknya, seluruh pasien yang mengalami perdarahan intrakranial seperti pada penelitian Amalia dkk, ${ }^{29}$ dilakukan skrining pemeriksaan inhibitor sehingga dapat dilakukan intervensi lebih dini apabila ditemukan inhibitor positif.

\section{Daftar pustaka}

1. The World federation of Hemophilia. Diagnosis and management of inhibitors to factor VIII and IX: an introductory discussion for physicians. California: The World Federation of Hemophilia; 2004.

2. Van de Berg. Risk of inhibitor development in children with hemophilia A. European Hematology. 2007;1:8-10.

3. Van den Berg SC. The multifactorial etiology of inhibitor development in hemophilia: genetics and environment. Semin Thromb Hemost 2009;35:723-34.

4. Lorenzo JI, Lopez A, Altisent C, Aznar JA. Incidence of factor VIII inhibitors in severe hemophilia: the importance of patient age. $\mathrm{Br} \mathrm{J}$ Haematol 2001;113:600-3.

5. Van der Bom JG, Mauser-Bunschoten EP, Fischer K, Van den Berg HM. Age at first treatment and immune tolerance to factor VIII in severe hemophilia. Thromb Haemost 2003;89:475-9.

6. Goudemand J, Rothschild C, Demiguel V. Influence of the type of factor VIII concentrate on the incidence of factor VIII inhibitors in previously untreated patients with severe hemophilia A. Blood 2006;107:46-51.

7. Gouw SC, Born JG, Auerswald G, Ettinghausen CE, Tedgard U, Berg HM. Recombinant versus plasmaderived factor VIII products and the development of inhibitors in previously untreated patients with severe hemophilia A: the CANAL cohort study. Blood 2007;109:4693-7. 
Grace N.A. Simatupang dkk: Faktor risiko timbulnya inhibitor faktor VIII pada anak dengan hemofilia A

8. Ragni MV, Ojeifo O, Feng J, Yan J, Hill KA, Sommer SS, dkk. Risk factors for inhibitor formation in hemophilia: a prevalent case-control study. Hemophilia 2009; 15:107482.

9. Addiego J, Kasper C, Abildgaard C. Increased frequency of inhibitors in African-American hemophilia A patients. Blood 1994;84:239.

10. Aledort LM, DiMichele DM. Inhibitors occur more frequently in African-American and Latino hemophiliacs. Hemophilia 1998;4:68.

11. Xue F, Zhang L, Sui T. Factor VIII gene mutations profile in 148 Chinese hemophilia A subjects. Eur J Hematol 2010;85:264-72.

12. Chen YC, Hu SH, Cheng SN, Chao TY. Genetic analysis of haemophilia A in Taiwan. Hemophilia 2010;16:53844.

13. Awidi A, Ramahi M, Alhattab D, Mefleh R, Dweiri M, Bsoul N, dkk. Study of mutations in Jordanian patients with hemophilia A: identification of five novel mutations. Haemophilia 2010;16:136-42.

14. Owaidah TM, Alkhail HA, Zahrani HA, Al Musa A, Al Saleh M, Riash MA, dkk. Molecular genotyping of hemophilia A in Saudi Arabia: report of two novel mutations. Blood Coagulation and Fibrinolysis 2009;20:415-18.

15. Harijadi, Djajadiman G, Akib Arwin AP. The prevalence of factor VIII inhibitor in patients with severe hemophilia A and its clinical characteristics. Paediatrica Indonesiana 2005;45:7-8.

16. Hay CR, Palmer B, Chalmers. The incidence of factor VIII inhibitors throughout life in severe hemophilia A in the United Kingdom. Blood 2011;117:6367-70.

17. Santagostino E, Mancuso ME, Rocino A. Environmental risk factors for inhibitor development in children with hemophilia A: a case-control study. British J Haematol 2005;130:422-7.

18. Maclean PS, Richards M, Williams M, Collins P, Lienser R, Keeling M, dkk. Treatment related factors and inhibitor development in children with severe hemophilia A. Hemophilia 2011;17:282-7.
19. Chalmers EA, Brown SA, Keeling D. Paediatric Working Party of UKHCDO. Early factor VIII exposure and subsequent inhibitor development in children with severe hemophilia A. Hemophilia 2007;13:149-55.

20. Manucci PM, Gringeri I, Pevyandi F, Santagostino E. Factor VIII products and inhibitor development: the SIPPET study (survey of inhibitors in plasma product exposed toddlers). Hemophilia 2007;13:65-8

21. Astermark J. Why do inhibitors develop? principle of and factors influencing the risk of inhibitor development in hemophilia. Hemophilia 2006;12:52-60.

22. Astermark J. Overview of Inhibitors. Semin Hematol 2006;43:3-7.

23. Gouw J, Van der Bom JG, Van den Berg HM, Zewald RA, Van Amstel JK, Mauser-Bunschoten EP. Influence of the type of F8 gene mutation on inhibitor development in a single center cohort of severe hemophilia A patients. Hemophilia 2011;17:275-81.

24. Miller CH, Hooper WC, Abshire TC. Factor VIII and factor IX mutations in U.S. hemophilia patients: Correlation with history of inhibitor and race/ethnicity. Hemophilia 2012;18:375-82.

25. Han JY, Lee JN, Lee SY. Identification of factor VIII gene mutations and carrier detection in Korean hemophilia A patients. Hemophilia 2007;13:331-3.

26. Leissinger C, Cooper DL, Solem CT. Assessing the impact of age, race, ethnicity and inhibitor status on functional limitations of patients with severe and moderately severe hemophilia A. Hemophilia 2011;17:884-9.

27. Gringeri A, Mantovani LG, Scalone L, Mannucci PM. Cost of care and quality of life for patients with hemophilia complicated by inhibitors: the COCIS study group. Blood 2003;102: 2358-63.

28. Nuss R, Soucie JM, Evatt B. Changes in the occurrence of and risk factors for hemophilia-associated intracranial hemorrhage. Am J Hematol 2001;68:37-42.

29. Amelia NC, Djayadiman G, Windiastuti E, Handryastuti S. Perdarahan intrakranial pada hemofilia: karakteristik, tatalaksana dan luaran. Sari Pediatri 2011;13:4. 